ISSN1027-5495. Functional Materials, 25, No.2 (2018), p. 401-405

doi:https://doi.org/10.15407/fm25.02.401

(C) 2018 - STC “Institute for Single Crystals"

\title{
Method for refractive index detection for emulsion concentration
}

\author{
Sihai Zhao, Ke Han, Gaopeng Yuan, Lin Wang \\ School of Mechanical Electronic and Information Engineering, China \\ University of Mining and Technology (Beijing), Xueyuan Rd., No.Ding 1, \\ 100083, Beijing, China
}

Received December 21, 2017

\begin{abstract}
The existing approaches to the determination of the oil concentration in the oil-water emulsion (where the dispersed phase is oil) are analyzed in accordance with the theory of light scattering and the change in the refractive index in the suspension. Based on the CCD method, an automatic measuring device was developed to measure the refractive index of the emulsion, the relationship between the concentration and the refractive index of the emulsion was determined.
\end{abstract}

Keywords: concentration of emulsion, detection, refractive index, charge-coupled device.

\begin{abstract}
Проанализированы существующие способы определения концентрации масла в масляноводной эмульсии (где дисперсной фразой является масло), использующие метод рассеяния света и изменение коэффрициента преломления в суспензии. На основе ПЗС-метода разработано автоматическое устройство для измерения показателя преломления эмульсии, определена взаимосвязь между концентрацией и показателем преломления эмульсии.
\end{abstract}

Метод визначення концентрації емульсії за показником заломлення. Sihai Zhao, Ke Han, Gaopeng Yuan, Lin Wang

Проаналізовано існуючі способи визначення концентрації масла в олійно-водній емульсії (де дисперсною фразою є масло), що використовують метод розсіювання світла і зміну коефіціента заломлення у суспензії. На основі ПЗС-методу було розроблено автоматичний пристрій для вимірювання показника заломлення емульсії, визначено взаємозв'язок між концентрацією і показником заломлення емульсії.

\section{Introduction}

Oil-in-water emulsions with a concentration between 3-5\% are extensively used as the transmission media in hydraulic supports and single hydraulic props in underground coalmines. The mass percentage of oil in an emulsion, i.e., the emulsion concentration, is a crucial indicator for evaluating the performance of the emulsion, and has a significant impact on the service life and operational performance of supporting devices in coalmines. An excessively low concentration would affect the performance of emulsion in terms of capacity of hard water resistance, stability, corrosion resistance, and lubricity, reducing the service life and overall performance of the supporting devices. On the other hand, an excessively high concentration would increase the costs and decrease the defoaming and swelling properties. Therefore, the rationality and stability of emulsion concentration have gradually become increasingly important indicators for the evaluation of coal production efficiency [1].

High-precision detectors capable of measuring real-time emulsion concentration are desirable in practical coal production. Based on the measured results, emulsion concentration in the tanks can be sustained in reasonable ranges by adding water or oil [2]. 


\section{Status quo of methods for emulsion concentration detection}

The primary method of emulsion concentration detection traditionally used in actual coal production is the refractometry approach. This approach requires manual sampling and reading by conducting regular sampling inspections, which, therefore, cannot be used for automatic real-time detection.

Moreover, due to the variety of emulsified oils used in coal mining processes, measuring the concentration of emulsions prepared from different types of emulsified oils using a certain type of refractometer can hardly reflect the actual emulsion concentration.

In addition to the manual handheld concentration meter method that is widely used at coalmines, a large number of emulsion concentration detection approaches have also been developed in China. Wang Zhengliang proposed a capacitance-resistance approach for detecting the concentration of emulsion[3,4]. In this approach, a measurement is conducted based on the basic trend that different values of concentration correspond to specific values of permittivity and resistivity. However, this approach has not been widely used due to the low reliability of detection. Currently, there are several frequently used methods of concentration measurement. Ultrasound detection measures emulsion concentration according to the fact that ultrasound exhibits different transmission speeds and attenuation levels in different media [5-8]. Infrared transmission measurement detects the concentration of emulsions based on the principle that infrared light demonstrates different degrees of attenuation when traversing emulsions with different concentrations[9]. Another method of concentration detection was developed based on the principles of the Venturi tube in fluid mechanics [10]. In recent years, optical methods of emulsion concentration detection have grown into a primary topic of study in this field, which mainly involves two methods - a refractive index detection approach based on the fact that light transmitted in emulsions with different concentration values has different refractive indices [11], and a turbidity detection approach based on the fact that emulsions with different values of turbidity have different turbidities [12, 13].

A key component of a high-precision, realtime emulsion concentration monitoring instrument is the sensor. The approaches mentioned above are all associated with various types of sensors. However, there still exists a lack of commercially available sensors for detecting the concentration of emulsion.
Let us analyze the relationship between the concentration of the emulsion and the refractive index. Oil drops in emulsions have sizes varying from several micrometers to tens of micrometers with a scattering distribution following the theories of Rayleigh scattering, Mie scattering, and Fraunhofer diffraction.

When the diameter of an oil drop is closely related to the wavelength of incident light, by assuming that the oil drop sizes are uniformly distributed, Rayleigh scattering can be used for analysis. Under the condition of Rayleigh scattering, a relationship between the nonlinear refractive index and the concentration of the medium can be derived, as shown below,

$$
\alpha_{0}=\frac{128 \pi^{5} n_{b}^{4}}{3 \lambda_{0}^{4}}\left(\frac{n^{2}-1}{n^{2}+2}\right)^{2} r^{6} N
$$

where $a_{0}$ denotes the diffraction loss per unit length, $n_{b}$ is the refractive index of a pure water medium, $n$ is the ratio of refractive index between an emulsified oil and water medium, $r$ is the radius of an oil drop, $\lambda_{0}$ is the wavelength of incident light, and $N$ is the number of particles per unit volume.

Nonlinear refractive index of the medium, $n_{2}$, can be calculated using Eq. (2),

$$
n_{2}=\frac{2 \pi n_{b}^{2}}{c k T} \frac{(n+1)(n-1)^{2}}{\left(n^{2}+2\right)} r^{3} V N
$$

where $V$ represents the volume of a single oil drop. It can be seen from Eq. (2) that refractive index of the medium is directly proportional to the number of oil drops per unit volume, $N$, i.e., directly proportional to the volume of oil drops per unit volume of emulsion, $V N$. Therefore, it can be inferred that the refractive index of the emulsion is directly proportional to the emulsion concentration.

Research on diffraction and refraction of comparatively large spherical drops of emulsified oil in the emulsion needs to be conducted according to the Mie scattering and Fraunhofer diffraction theories. Due to the complexity of the associated theories, research on the relationship between equivalent refractive index and concentration has not yet been reported and needs further exploration. Nevertheless, we can still predict that the refractive index of an emulsion should be intensively associated with the size distribution of emulsified oil drops in the emulsion and the number of drops per unit volume. 


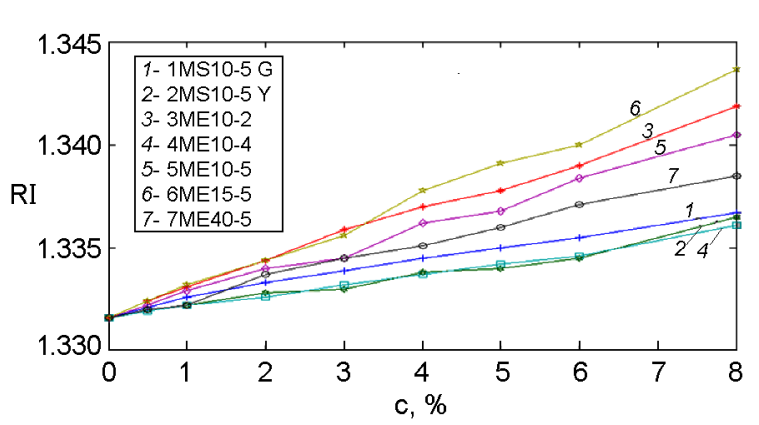

Fig.1 Relation curves of concentration and refractive index of emulsions in various types

Researchers in China obtained the concentration-refractive index curves for emulsions of the commonly used types from experimental studies [15]. According to the operational requirements on emulsion concentration specified in coal production, emulsions with eight values of concentration $(0.5 \%, 1 \%, 2 \%, 3 \%, 4 \%, 5 \%, 6 \%$, and $8 \%)$ were prepared using concentrated solutions and emulsified oils in seven types (MS10-5 G, MS105 Y, ME10-2, ME10-4, ME10-5, ME15-5, and ME40-5), as shown in Fig. 1.

It can be observed from Fig. 1 that the refractive indices of emulsions in various types all monotonously ascend with the concentration. Variations of refractive index are fairly small; from the lowest concentration level, 0.5 $\%$, to the highest concentration level, $8 \%$, the maximum and minimum variations are 0.1418 and 0.0541, respectively. MS10-5G, ME10-2, and ME10-4 exhibit superior linear properties within the whole range, while ME15-5, MS105, ME10-5, and ME40-5 show good piecewise linear characteristics.

In order to more accurately measure the concentration, table lookup and linear interpolation methods were adopted for processing the detected signals. In other words, a concentration-refractive index table was established with an interval of $0.5 \%$ concentration. Concentration in each interval was inversely deduced by conducting linear interpolation on detected refractive index piecewise-point data (already saved in the table).

\section{Approach of refractive index detec- tion for emulsion concentration}

Figure 1 illustrates that there exists a certain relationship between emulsion concentration and refractive index. Given the type of a certain emulsion, the emulsion concentration can be obtained by using look-up table or interpolation methods based on the experimentally measured refractive index data.

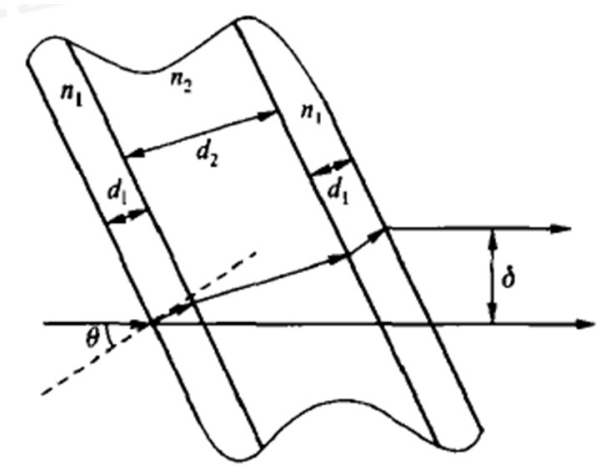

Fig.2 The schematic of refraction of the laser beam traversing the sample cell

The refractive index of liquids can universally be measured using five methods: laser radiation, diffraction grading, optical fiber Young's interference, surface incidence, and CCD-based detection [16]. Moreover, the refractive index can also be calculated based on the detected critical angle of total internal reflection [11, 17], which, however, is comparatively complicated in practice.

In this study, the concentration of emulsion was calculated according to the concentrationrefractive index curve, where the refractive index of the emulsion was detected using CCD. The principle of refractive index detection using CCD is illustrated in Fig. 2 [18].

When a laser beam is obliquely incident into a rectangular sample cell filled with liquid, an offset of transmitted light, $\delta 1$, will occur. Under the same angle, another offset of transmitted light traversing the empty cell, $\delta 0$, will be produced. The refractive index of the liquid to be detected is actually related to these two offsets, but not to the refractive index or thickness of the sample cell wall. In the CCD-based detection method, the refractive index of the liquid to be measured is generally calculated based on the laser beam offsets that are automatically detected by CCD [16], as shown in Fig. 2.

$$
\begin{gathered}
n_{2}=\left[1+\left(\frac{\cos \theta}{\sin \theta-\Delta / d_{2}}\right)^{2}\right]^{1 / 2} \sin \theta, \\
\Delta=\delta_{1}-\delta_{0},
\end{gathered}
$$

where $n_{2}$ - refractive index of the emulsion, $\theta$ - incident angle of the laser beam, $d_{2}$ - distance from the front wall to the back wall of the sample cell,

$\Delta$ - offset difference of the laser beam between traversing the empty sample cell and traversing the sample cell filled with emulsion. 
Table. Refractive indices of ME10-2 with different values of concentration

\begin{tabular}{|c|c|c|c|c|c|c|c|c|c|c|}
\hline C, \% & $\begin{array}{c}0 \\
\text { (Water) }\end{array}$ & 0.5 & 1 & 2 & 3 & 4 & 5 & 6 & 8 & $\begin{array}{c}100 \\
\text { (Oil) }\end{array}$ \\
\hline $\begin{array}{c}\text { Abbe } \\
\text { refractometer }\end{array}$ & 1.3316 & 1.3324 & 1.3331 & 1.3344 & 1.3359 & 1.3370 & 1.3378 & 1.3390 & 1.3419 & 1.4603 \\
\hline \begin{tabular}{c} 
CCD Method \\
\hline
\end{tabular} & 1.3314 & 1.3321 & 1.3329 & 1.3340 & 1.3355 & 1.3367 & 1.3375 & 1.3386 & 1.3416 & 1.4599 \\
\hline
\end{tabular}

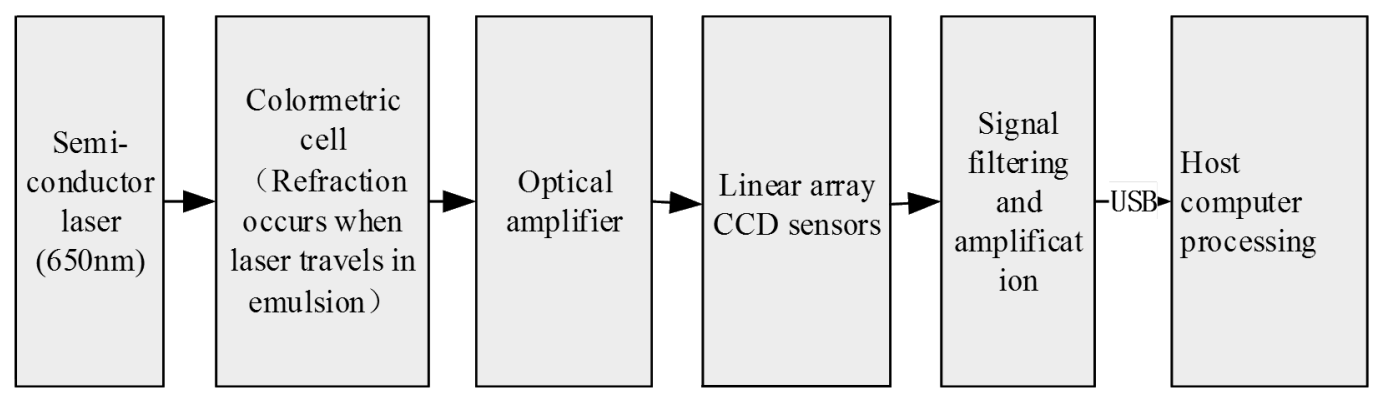

Fig.3 The schematic diagram of a refractive index detection device for concentration of emulsion based on CCD testing technology

Emulsion concentration can be obtained using CCD by following the specific steps below-1) arrange the CCD linear array detectors along the direction perpendicular to that of the laser beam for detecting the intensities of light traveling through different positions; 2) input the digital signals that are transformed from the CCD output analog video signals under the action of $\mathrm{A} / \mathrm{D}$ conversion into the micro-computer, and calculate the position of the optical axis $\delta$ using curve fitting; 3) solve for $\Delta$ using Eq. (4) based on the practically measured optical axis positions $\delta_{1}$ and $\delta_{0}$, and substitute $\Delta$ into Eq. (3) to calculate the refractive index of the emulsion; 4) acquire the emulsion concentration using the look-up table or interpolation.

In practical measurement, refractive index is also related to the emulsion temperature. Therefore, temperature compensation needs to be considered for a calculation that is more accurate.

\section{Experimental}

According to the CCD-based detection method of refractive index measurement, a set of devices for detecting the refractive index of emulsions used in coalmines, based on the CCD detecting technique, were proposed in this re- search, whose schematic of detection is shown in Fig. 3.

In this setup, a R650D5-3 red dot laser module with a wavelength of $650 \mathrm{~nm}$ was adopted as the semiconductor laser. A Toshiba TCD1304AP with a pixel size of $8 \mu \mathrm{m} \times 200 \mu \mathrm{m}$, a total pixel number of 3648 , and a wavelength response range of 300-1100 nm was used as the CCD linear array detector. The high-resolution CCD detector uses a USB connection to transfer images to a computer, with the option of 16-digit A/D conversion. A Type-72 glass colorimetric cell manufactured by the Shanghai No. 4 Industrial Glass Factory was adopted as the sample cell to keep the emulsion, with an optical length $d 2=10 \mathrm{~mm}$ and incident angle of $30^{\circ}$. For the optical amplification, a double-lens confocal optical system was used to magnify the offset of the laser beam passing through the colorimetric cell. The confocal optical system was composed of two plano-convex lenses (GL11010-016 and GL11-050-160) manufactured by Beijing Golden Way Scientific Co., Ltd.

In this research, the proposed method of emulsion refractive index detection was verified by conducting experiments on prepared ME10-2 emulsions with eight concentration values, i.e., $0.5 \%, 1 \%, 2 \%, 3 \%, 4 \%, 5 \%, 6 \%$, and $8 \%$. 
Results of experiments conducted at an ambient temperature $\left(20^{\circ} \mathrm{C}\right)$ are listed in Table.

It can be seen from the table that:

- Refractive index can be measured using CCD. Because concentration of an emulsion is related to its refractive index, this approach can be used to determine the concentration of the emulsion.

- There are some discrepancies between refractive index values measured using CCD and Abbe refractometer, which is potentially resulted from the distinct light sources used.

- In order to obtain the concentration of a certain emulsion by using look-up tables or interpolation based on the CCD-detected refractive index, the specific type of emulsion as well as the corresponding relationship between its concentration and refractive index needs to be acquired a priori.

- For an emulsion of an unknown type, due to the fact that emulsion concentration and refractive index essentially have a linear correlation (shown in Fig. 1), the refractive index of an emulsion with a given concentration prepared from the emulsion to be measured can be detected by solving the linear equation of concentration and refractive index. On this basis, concentration of emulsions of this type can be calculated in the future using the linear equation based on the detected refractive index data.

\section{Conclusion}

Existing methods for emulsion concentration measurement were analyzed in this study. According to the concentration-refractive index curve, an approach to determining concentration by detecting the refractive index of the emulsion was proposed. An automatic detection method based on CCD-detected refractive index was developed and experimentally verified.

- The major achievements of this effort can be concluded as follows:

- Existing emulsion concentration detection approaches frequently adopted in coal mining were analyzed.

- Based on optical refraction theories, calculating the concentration of emulsions by measuring the refractive index was verified to be feasible.

- An automatic detection method of emulsion refractive index using CCD was proposed, and experiments were conducted on the emulsions with eight different concentration levels prepared from a certain type of emulsified oil.
Experimental results demonstrate that the refractive index of a certain type of emulsion can be acquired using the CCD measuring method, and, based on which, the concentration of the emulsion can be obtained by referring to the relationship between refractive index and concentration for this particular type of emulsion.

- The proposed method can be realized in practice by developing an intelligent emulsion concentration sensor based on single chip microcomputer (SCM).

\section{References}

1. Zhou, X.X., Yang, X.W., Zhang, X.Y. Lubr. Eng. 3, 85, 2003 .

2. The State Administration of Work Safety, the State Administration of Coalmines Safety, the Procedures on Coal Mine Safety. China Coal Industry Publishing Home, 2009.

3. Wang, Z.L., Zhao, D.Q., Tang B., et al., J.China Univ. Mining Techn., 23 , 9, 1994.

4. Wang,Z.L., Zhao,S.H., Tang,B., et al. J.China Univ. Mining Techn., 23 , 16, 1994

5. Wang, X.L., Chai, G.Y., Xu S.L. Coal mine machinery, 7, 45, 2002.

6. Wang. Z.L., Lou, F.,X., Zhao, S.H.(1995), Machine tools and hydraulics, 3, 138, 1995.

7. Yan, L.N., Zhang, T.M.. J.Hainan Normal Univ. (Nature Science), 1, 33, 2010.

8. Wang, D., Wang, B., Li C.X., et al., J.Hainan Normal Univ. (Nature Science, 16, 8, 2004.

9. Gu D.Y., Liu W.J., Zhu H. Electr. Meas.Instr., 35, 43, 1998.

10. Ding, E.J., Chen, G.Z., Liu, Y.X, Chinese. J.Sci. Instr., 23 , 333, 2002.

11. Lu L.Q., Li W.Y., Fluid Power Transm.Control, 4, 55, 2009.

12. Patent 200610112652.X, China.

13. Zhao, S.H., Li, W.C., Li, M., et al. , J.China Coal Soc.,36(1), 157, 2011.

14. P. W. Smith, P. J. Maloney, and A. Ashkin. Opt. Lett. 7, 347, 1982.

15. Guo, Y.C. Research and Design of Emulsion Concentration Detecting Platform Based on Light Refraction Law. Master Dissertation of China University of Mining and Technology (Beijing), 2013.

16. Xin, D.Q., Zhu, M., Xie, Y.L., et al., College Physics, 26, 34, 2007.

17. Qian, J.Q., Wang, D.S., Chen,J.L. , Opt. Techn., 28, 65, 2002.

18. Zhang, Q.F., Guo M.T., Yang H.B., et al., Semicond. Optoelectr., 21(3), 229, 2000. 